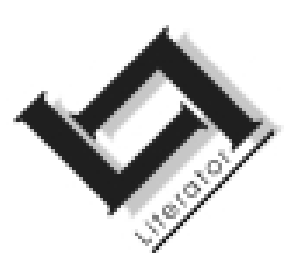

\title{
Beyond the walls of the lunatic asylum: Christopher Hope's early fiction
}

\author{
Felicity Wood \\ English Programme Unit \\ University of Fort Hare \\ ALICE \\ E-mail: fwood@ufh.ac.za
}

Abstract:

Beyond the walls of the lunatic asylum: Christopher Hope's early fiction

This article examines an under-explored aspect of Christopher Hope's early fiction: its capacity to suggest the potential for imaginative and psychological freedom through its comic, carnivalesque qualities. Hope produced various novels and stories set in South Africa during the 1950s and 1960s, including A Separate Development (1981), Black Swan (1987) and the short story collection Learning to Fly (1990). It is argued that Hope's vision in these works tends to be perceived as essentially satirical, ultimately limited by bleakness and pessimism; while the carnivalesque, potentially liberatory aspects of his writing tend to be overlooked. By utilising comic and carnivalesque features Hope's work indeed offers creative, liberated ways of apprehending reality. Mikhail Bakhtin's discussion of the ability of the carnivalesque to open up new ways of seeing, through the "nonofficial" versions of reality that it proffers, is particularly relevant in this regard. It is argued that this latter aspect of Hope's work is especially significant, bearing in mind the sense of constraint and confinement that seemed to dominate much of South African fiction during the apartheid era and that still remains a key concern in many postapartheid novels.

Opsomming:

Buite die mure van die gestig: Christopher Hope se vroeë fiksie Hierdie artikel ondersoek 'n aspek van Christopher Hope se vroeëre fiksie wat tot dusver baie min aandag gekry het, naamlik die vermoë daarvan om verbeeldings- en psigologiese vryheid te suggereer op 
grond van die komiese en karnavaleske eienskappe van sy werk. Hope het gedurende die vyftiger- en sestigerjare verskeie romans en verhale wat in Suid-Afrika afspeel, die lig laat sien, onder meer $\boldsymbol{A}$ Separate Development (1981), Black Swan (1987) en die kortverhaalbundel Learning to Fly (1990). Die artikel toon aan dat die persepsie dat die perspektief wat Hope se werk bied, satiries geïnterpreteer kan word en deur uitsigloosheid en pessimisme aan bande gelê word, oorstyg kan word kan word deur te let op die aanwending van karnaveleske grepe en die potensieel bevrydende aspek daarvan wat dikwels oor die hoof gesien word. Deur die gebruik van komiese en karnavaleske tegnieke bied Hope se werk 'n kreatiewe, bevrydende manier om die werklikheid te benader. Mikhail Bakhtin se bespreking van die karnavaleske se vermoë om deur "nieamptelike" weergawes van die werklikheid 'n heeltemal nuwe perspektief op die werklikheid te bied, is in hierdie opsig veral tersaaklik. Laasgenoemde faset van Hope se werk is belangrik as in gedagte gehou word dat die idee van beperking en inperking oorheersend was in Suid-Afrikaanse fiksie gedurende die apartheidsera, en selfs tans - na apartheid - nog 'n kerngegewe in baie romans is.

\section{Introduction}

This article explores an under-investigated dimension of Christopher Hope's early fiction: his fantastical, carnivalesque transformations of aspects of South African society during the apartheid era. Through this, it is argued, Hope's fiction not only offers opportunities for subversive ridicule of representatives of the established order but also holds out the possibility of psychological and imaginative liberation.

Hope grew up in the 1950s and 1960s, the era of Prime Ministers Hendrik Verwoerd and B.J. Vorster. Novels such as $A$ Separate Development (1981), Black Swan (1987) and the short stories in Learning to Fly (1990), a revised edition of Private Parts and Other Tales (1982), are set during this period. ${ }^{1}$ There are several reasons why these particular novels and stories are worth re-visiting. Firstly, Hope's most striking work seems to be that which engages with South African society during the dark days of Nationalist Party rule. Novels set outside South Africa, such as The Hottentot Room (1987), which takes place in Europe, and later fiction, such as Me, the Moon and Elvis Presley (1997), set in post-apartheid South

1 Only a few stories from this collection will be examined in this article. The stories selected provide a particularly clear illustration of some broader tendencies in Hope's work. 
Africa, lack the outrageous humour and imaginative vitality of Hope's earlier writing. Secondly, while his artistic vision in works dealing with South Africa under apartheid tends to be viewed as primarily satirical in nature, characterised by a blackly cynical vision and culminating in images of death and defeat, Hope himself ascribes a far larger purpose to his fiction. This study argues that this other dimension of Hope's early novels and stories - which has more often than not, been overlooked - remains of relevance to South African fiction today.

Certain forms of freedom represent an important aspect of Hope's early writing, and in this respect his work differs strikingly from a great deal of South African fiction in English produced during the apartheid era. In 1992, J.M. Coetzee described South African literature as "a literature in bondage ... a less than fully human literature, unnaturally preoccupied with power and the torsions of power, unable to move from elementary relations of contestation, domination and subjugation to the vast and complex human world that lies beyond them" (Coetzee, 1992:98). Various other writers and critics have used similar images to describe pre-1994 South African fiction. "A sense of space seems to have oppressed us in our souls as well as in our bodies", Nadine Gordimer lamented in 1973; "we have shut ourselves in" (Gordiner, 1973:39). Moreover, there was the tendency to view the South African situation as all-engrossing and all-encompassing. As Kaizer Nyatsumba remarked regretfully in 1992: "For us, the world begins and ends with apartheid within the borders of South Africa" (Nyatsumba, 1992:94). Trapped within a narrowly delineated terrain, writers tended to recycle time-worn themes and motifs - such as inter-racial sexual encounters, white liberal angst, racial polarities - over and over again. In 1985, Hope complained of "a certain sameness, a predictability, a certain familiar ache in the heart of the South African novel which has become increasingly burdensome" (Hope, 1985:43).

Yet, those instances in which these confines were transcended and possibilities for certain forms of liberation were offered are noteworthy particularly because of their exceptional nature. The short stories in Njabulo Ndebele's Fools (1983) and the comic writing of Casey Motsisi represent some illustrations of these - as does, against all surface appearances, Hope's early fiction.

\section{The satirical}

At first glance, there does not seem to be much room for images of liberation in Hope's novels and stories set in South Africa during the 
apartheid era. The nature of a society based on an ideology of racial dominance is one that, in Hope's eyes, can be best expressed in terms of images of enclosure and imprisonment. In his view, life under apartheid was "a siege existence which had about as much joy in it as you will find in Potchefstroom on a wet religious holiday" (Hope, 1984b:286). He describes South Africa during this period as "the capital of walls" (Joffe, 1989:93), a lunatic asylum (Wood, 1998:60) and a zoo, "in which we build our own cages, and not only that, but are encouraged to do so" (Joffe, 1989:104). Hope seeks to highlight the weird, warped qualities of this type of society in his fiction.

As an introduction to certain key aspects of Hope's fictional technique, we could consider a passage from his first novel, $A$ Separate Development (1981). The book is set in South Africa in the 1950s, "in doldrum country, where nothing shifts or alters" (1981: 193), except the career and expectations of Harry Moto, the hapless narrator, whose problems start as his racial group becomes more and more obviously indeterminate. Finally, the security policemen, alarmed by the way in which Harry eludes all clearly delineated racial categories, detain him. At one point, they attempt to torture him, in a scene which, rather than steeping itself in moral anguish, careers along on a wave of manic comedy. Two inept members of the Special Branch, Pielletjies (sic) and Ou Neels, try to apply an electro-shock apparatus (described as resembling "a souped-up meat mincer") to Harry's genitals. Their equipment proves defective and so, at a moral and rational level, are the arguments they and the other servants of the state in the book trot out in an attempt to assert their right to exercise control over the lives of others. Pielletjies, for instance, quotes from the Old Testament when physical violence fails in an attempt to make Harry see what he regards as reason:

Pielletjies found a bit he liked and smoothed back the pages with a huge palm. 'Here, listen ... "Behold, to obey is better than sacrifice, and to hearken to the fat of rams." Samuel 15:22.'

'He means that next time we'll fry your balls off.' Ou Neels was angrily forcing the machine back into its canvas bag (Hope, 1981:221-222).

For Pielletjies, the archaic injunctions that he reads represent a command to submit to the particular system of authority he serves, while Ou Neels registers only one word in the whole passage, "fat", which he promptly manipulates to suit the situation. The scene begins on a note of burlesque, with Pielletjies frantically and futily 
cranking the handle of the electro-shock device. The scene ends in incongruity and absurdity, as the lofty rhetoric of the Old Testament is converted into the language of the servants of the Nationalist government, its dictates becoming abusive, racist threats. This scene deals particularly with the violence - both physical and verbal - that the agents of the state used to reinforce their position, but it reduces both them and their violence into features in a twisted farce.

Hope's fiction contains a great many comparable passages. Consequently, critics tend to view his vision as primarily satirical, ultimately limited by bleakness and pessimism. (At the conclusion of A Separate Development, for instance, Harry's "accidental" death in detention seems imminent.) The most significant force in Hope's novels and stories, many critics argue, is the system of political control that co-opts or crushes his protagonists. For instance, in a review of $A$ Separate Development and Private Parts and Other Tales, Anthony Delius (1982:4) argues that because these texts depict South Africa as "a bedlam in which everybody is going steadily insane" watched over by the all-seeing Security Police, the overall effect "is to create a feeling of sinking into an underworld of calcified demons". In his discussion of Kruger's Alp (1984), a paranoia-laden vision of secret plots and political manipulations, Michael Green (1997:281) maintains that Hope allows no space for political choice and moral responsibility, and the target of his satire is ultimately hope itself. While indicative of his objection to all forms of authoritarianism, the antipathy that Hope expresses towards leftwing beliefs in his fiction and critical writing could also be cited in evidence of this.

For example, the most optimistic, idealistic character in Kruger's Alp (1984), Looksmart Dladla, retains his faith in his convictions only because he has been brain-damaged during a police interrogation, while a figure such as Jakes Mpahlele in Learning to Fly, who is essentially the same as his torturer, embodies Hope's conviction that the possibility of positive, constructive change in South Africa is a delusion - a belief which, if anything, became stronger after 1994. In 1999, he described South Africa as "the capital of hypocrisy, with the ANC as its high church" (Schoonakker, 1999:33). Hope's most recent South African novel, Me, the Moon and Elvis Presley (1997), while highlighting many of the very real absurdities of post-apartheid society, also makes clear that Hope views the political transformation in South Africa as essentially empty and meaningless.

It could be argued that the special impact of Hope's fiction lies in the claustrophobic rigidity of the society he presents: a lunatic asylum 
hemmed in by insurmountable walls, dominated by all-seeing, allcontrolling warders. Such a perception would not be entirely accurate, however, for the most remarkable quality of Hope's work is the way that, despite its seeming cynicism and despair, it manages to surmount defeat. Through this, it calls into question the sense of inevitability inherent in Elleke Boehmer's (1998:44-45) assertion that South African fiction during apartheid was unable to conceive of "a convinced and a convincing opening up and testing of options". She - and many other critics - have ignored the particular type of possibilities presented by a writer such as Hope.

\section{The carnivalesque}

There is more to Hope's comic vision than the "reduced" laughter (Bakhtin, 1984:38) of the purely satirical. We encounter an ambivalent mirth which, while it derides, undermines and negates, is at times also celebratory and affirmative. This, of course, is how Mikhail Bakhtin (1984:13) describes the laughter of the carnival. Above all, the most significant carnivalesque dimension of Hope's stories and novels lies in their fantastical transformations of South Africa during the apartheid era. ${ }^{2}$

The circus-like, blackly playful qualities in Hope's fiction arise particularly out of the "desperate need" that he felt from childhood onwards, growing up in a white, middle class Johannesburg suburb, for "variety, change, movement" (Hope, 1988:68). He describes, however, how he came to discover that "events and incidents could ... supply surprises if you looked below the surface of things; if you did so you began to see that the real life lay in the unexpected and the illicit, in unforeseen arrivals, novel departures, in unclassifiable careers and dubious callings" (Hope, 1988:38).

This calls to mind Bakhtin's description of Rabelais's artistic method, which might have been expressly describing some of the key features of Hope's technique:

The essence of this method consists, first of all, in the destruction of all ordinary ties, of all the habitual matrices ... of things and ideas, and the creation of unexpected matrices,

2 Kruger's Alp tends to lack these festive qualities and for this reason this article focuses on those stories and novels which share comparable carnivalesque features. 
unexpected connections, including the most surprising logical links ... and linguistic connections (Hope, 1981:169).

The essential function of the carnival is to provide an escape from the usual official way of life, by offering a "completely different, nonofficial aspect of the world" (Bakhtin, 1984:5-6). Likewise, this constitutes one of the key functions of the carnivalesque aspects of Hope's fiction. For instance, his most shockingly funny story, the title tale from Learning to Fly, concludes with a particularly unexpected and grotesque overturning of the established order. Colonel Rocco "Window Jumpin"' du Preez, a security police interrogator, is renowned for formulating "Du Preez's law", which posits that the way particular political detainees commit suicide is determined by their race. Whites, he maintains, prefer to hang themselves, while blacks choose to jump out of windows - which he ascribes to black superstition:

Everyone knows that in extreme instances your average blackie will believe anything ... It's as if despite the evidence of their senses they believed that if only they could practise enough they would one day manage to take off (Hope, 1982:2-3).

Du Preez presents his "law" in a logical manner, yet like some logical deductions it is inherently ridiculous - as is made obvious in the conclusion of the story:

We have no more facts to go on. All is buried in obscurity or say, rather, it is buried with Du Preez who plunged from his window down to the landing field at the most horrible speed, landing on his head. Jakes Mpahlele [sic] has never spoken of his escape from Colonel 'Window Jumpin' du Preez. All we have are the stories. Some firmly believe to this day that it was done by a special magic and Mpahlele had actually learned to fly and the colonel on looking out of his window was so jealous at seeing a black man swooping in the heavens that he had plunged after him on the supposition, regarded as axiomatic in the days of the old regime, that anything a black man could do a white man could do ten times better. ... All that is known for sure is that Du Preez lay on the landing field like wet clothes fallen from a washing line, terribly twisted and leaking everywhere (Hope, 1982:9-10).

The grisly jauntiness of the opening comes full circle here. At the beginning of the story Du Preez derived cynical, superior amusement from the way in which black detainees under his control committed suicide. Now, at the close of the narrative, he ends up, like many of his own prisoners, on the infamous "landing field", the 
area directly below the windows of the State Security building. To draw on Hope's phraseology above, Du Preez's "unexpected arrival" at this site parallels Mpahlele's "novel departure" from his captors. The former's demise becomes a subject for comedy, as it takes the notion of innate racial superiority to its extreme conclusion, highlighting the inherent craziness of this idea in doing so. The ending of the story is startling, yet it unfolds, with a certain logical inevitability, the racist suppositions paraded at the beginning of the narrative. In a comparable way, of course, in the carnivalesque those in positions of power are made to seem essentially preposterous, as the follies and vanities underlying many notions of social and political superiority become inflated to outrageous proportions.

Both "the unexpected and the illicit" (to quote Hope again) come to the fore in the short story "The Kugel". The two established campus groupings, the student activists and the husband-hunting "kugels", are threatened by the fact that Joel Wolferman takes neither them nor himself seriously. The story concludes with the Security Police catching Wolferman in bed with Barney Tembisa, the token oppressed black (the students all assumed that he was in bed with one of the kugels).

They were marched out by the policemen into the clear morning light. Wolferman in his shorts and rhino teeshirt and beside him, Tembisa, who for the sake of decency had been draped in the gold patterned bedspread which was far too large for him and dragged behind him like a cloak. Belinda through her pain and fury recognized something absurdly dignified in the progress of this strange couple, the tall striding figure of Wolferman and beside him the richly swatched, plump figure of his unlikely queen accompanied by their uniformed attendants, yes, that was it, she thought ... there was something hideously regal about the procession of Wolferman and his kugel to the waiting police van (Hope, 1990:124).

For a character such as Belinda, who views herself utterly seriously, the only possible response to this unexpected revelation (which exposes the inadequacy of her understanding) is one of "pain and fury". Barney Tembisa's cumbersome finery adds to the incongruous effect of the scene, turning him into a "queen" (in more than one sense of the word) and the lovers' progression to the police van into a parody of a royal procession. However, in true carnivalesque fashion, the targets of Hope's mockery are not the central figures in the procession, Wolferman and Tembisa, but the bystander, Belinda and the other students. Shocked and outraged, they cannot 
incorporate this event into their narrow view of how things should be, and their inability to cope with the situation is reflected in the use of terms like "absurdly" and "hideously". This passage is just one of many scenes in Hope's fiction in which the carnivalesque creates opportunities for subversive laughter at the expense of the representatives of various establishments, who "[put forward] the predominant truth as eternal and indisputable" (Bakhtin, 1984:5, 9).

While all Hope's fiction contains carnivalesque features, it is in Black Swan (1987), his last novel dealing with South Africa under apartheid, that they are most marked. The novel's carnivalesque qualities arise from the behaviour of the central character, Lucky, who is always "determinedly elsewhere" (Hope, 1987:1), absorbed in his private imaginative world. Inspired by a film of Swan Lake, his life becomes dominated by the longing to dance. The General, a political activist, sees Lucky's determination, misinterprets his desire to dance as an expression of unshakable commitment to political liberation, and recruits him into the armed struggle. Lucky is captured and at his trial township youths appear, brandishing ballet shoes as revolutionary symbols. (Of all the incongruous images in Hope's work, this is perhaps one of the most irreverent.) Before he is sentenced, Lucky announces:

'I know that a small bird can break a big egg. An ostrich can speak with the voice of a lion. And one day we will all dance.' ...

There was a surge of excitement from the gallery and several more pairs of ballet shoes were displayed defiantly by their laces (Hope, 1987:88).

In its fantastical quality, Lucky's statement is also a parodic echo of the bombastic nature of many political utterances. Its portentous images seem, on the surface, to suggest a profound symbolic message, but are, in actual fact, meaningless - although this does not matter to his ardent supporters, who read into his words what they wish to hear. Lucky's ludicrous responses also undermine the solemnity of his trial and all attempts by authorities to bring him under their control. In Bakhtin's terms, his behaviour represents "a critique on the one-sided seriousness of the lofty direct word" (Hope, 1981:55).

It could, nonetheless, be argued that this type of ridicule is powerless in itself. After all, it does not have the capacity to alter the inevitable fates that await either Wolferman or Lucky in any significant way. As we know, carnival laughter can mock established 
structures and authorities, yet it cannot overcome or destroy them. The carnival is, in fact, sanctioned and enclosed by the dominant establishment.

That granted, the carnivalesque remained an important symbolic presence in the lives of those who took part in it. In his Prologue to Bakhtin's Rabelais and His World, Michael Holquist (1984:xiii-xxiii) draws attention to the fact that Bakhtin was writing during the 1930s, at the height of Stalinist repression. Similarly, state control was at its strongest during the period when these novels and stories by Hope were set. In such a climate, although the carnivalesque obviously did not have the capacity to create physical freedom in any lasting sense of the word, it did, through its subversive forms, affirm psychological and spiritual liberation. Bakhtin is, therefore, justified in claiming that a "striking peculiarity" of carnival laughter is "its indissoluble and essential relation to freedom" (Holquist, 1984:89). In a comparable way, art exerts its power at a symbolic level and while it does not necessarily bring about freedom in actual life, it can open up possibilities for imaginative, emotional and psychological emancipation, through its capacity to touch us profoundly in these areas. Moreover, by creating a mental climate within which the idea of freedom is kept alive, art can prefigure physical liberation.

Michel Foucault (1977:308) describes the way in which a prison and other carceral mechanisms exist to exercise "a power of normalisation" over members of a society who are regarded as disrupting, or deviating from the norms - in other words, the rules of that society. In the extended prison that is Hope's South Africa, characters who are beyond the reach of this sort of "normalisation" play a crucial role. For example, the central protagonists in "The Kugel" and Black Swan are not bound by standardised, conventional codes of conduct. Instead, they are determined, at all costs, to live their lives the way they feel they should be lived. Through their contrary behaviour, they assert certain freedoms within the prim conformity of the societies they inhabit. Lucky, especially, is a figure close to Hope's heart:

In a sense he doesn't accept anything he's told because he will be neither saboteur nor bomber nor soldier nor good upstanding muscular South African, and yet what he wants is entirely modest. It's not particularly notable, but in the context of our country it's both misunderstood, dangerous, reprehensible all the reasons for which one applauds the way Lucky is, and would like to see more people the way he is (Wood, 1998:61). 


\section{Escape}

Despite Hope's admiration for Lucky, there seems little that is enviable or appealing about his character's situation. His name in fact seems deeply ironic, for he is consigned to the poverty and violence of township life, treated with bewilderment and scorn as a result of his autism and is eventually condemned to death. Yet he possesses what is, in Hope's eyes, the greatest gift of all - a powerful imagination, through which he turns his situation, dismal and disastrous as it may be, into a source of marvels. He periodically "flies away", recreating people and his surroundings in the process:

She knew that look. He was doing things with the prophetess. It was not right. You should not do as you liked with other people the way Lucky did. Nor should you fly away in your head whenever you felt like it. Muriel feared for the boy in the township. Some day someone would get angry with him.

Lucky felt none of her concern. He was watching Marigold greedily. He saw her in the sky, floating heavily in her green clothes, a dark storm cloud full of rain that drifts over fields of young maize - round, fat and full of promise (Hope, 1987:13).

At this point, we should consider the possibility that some of Hope's readers might endorse Granny Muriel's views. A very obvious criticism that could be levelled against fantastical reconstructions of reality - and, indeed, against much fiction containing fantastic elements - is that it appears to advocate a form of individual escapism to dream realms that have little or no connection with real life. Lucky is, after all, deranged.

Hope defends the impulse to escape by arguing that it represents an integral aspect of creativity. In terms that call Lucky's "fly[ing] away" to mind, Hope describes his own delight in reading, which he links, later on, to his desire to become a writer. After depicting how, at the age of four, he experienced a sense of loneliness and dislocation as a result of major changes in his family life, he states:

[A]ll combined to give me the most frantic need to escape. ... I was lucky, for close at hand lay a means of flight more effective and long lasting, and ultimately, more potent than anything dreamed of in the fairy tales on which I doted.

It was about this time that I learnt very quickly, and hungrily, to read. ... [E]ach time I sat down with a book, ... I knew at least that I was off and elsewhere (Hope, 1988:47-48). 
Words like these do not necessarily invalidate the criticisms cited above. Instead, some might choose to quote Hope's description as evidence in support of such objections, positing that if artistic creativity springs from a dissatisfaction with reality it will inevitably result in a withdrawal from the latter. In critically evaluating the value Hope attaches to the idea of imaginative escape, we could begin by examining where his desire for physical escape from South Africa ultimately led him.

Hope does not call himself an exile or an expatriate, but rather "an escapee" (Hope, 1984b:285). However, his physical escape from the constraints of the South African situation did not so much lead towards greater political freedom as into a cage of another kind: that of increasingly overt political conservatism. Hope would dispute this, since he is strident in his renunciation of political ideologies. ${ }^{3}$ Yet, Hope's criticisms of left-wing politics and his dismissal of the political transformation in South Africa as essentially fraudulent, are expressive of a particular ideological slant and could certainly be used to support the views of conservative political groupings. Does the imaginative escape that Hope advocates also, paradoxically, lead into a form of enclosure: an opting for the blinkered confines of a dream world that deliberately shuts itself off from the reality from which it has fled? It could, perhaps, be argued that the degree of disturbing naivete evident in his apparent rejection of all political positions, combined as it has been with a number of assertions that are clearly ideologically laden, also makes itself felt in his valorisation of the role of escape in fiction.

Yet, despite the importance he attaches to the idea of escape in various different senses of the word, Hope does not view his fiction as a means of evading the South African situation, but rather as a way of "fac[ing]" it (Joffe, 1989:97). In this regard, his position as an "escapee" from the country itself played an important role. "Anger recalled in exile is my spur" he observes, "you need space to swing an axe" (Hope, 1996:112). In Hope's view, his escape led back, along unique and intriguing paths, to the place from which he had departed, providing a means of alternative, liberated forms of imaginative interaction with South Africa. "Reality", he remarks, "was so deadly boring when it wasn't lethal that one tried for other ways of

3 For example, Hope tells Phil Joffe: "[B]ecause I come out of South African society, in which the entire society has been demarcated into groups, ... where all thinking is group thinking, I have a natural abhorrence for any group at all" (Joffe, 1989:101). 
being and other ways of writing" (Wood, 2001:304). ${ }^{4}$ In doing this, he draws our attention to areas of life that those endorsing the various centralised notions of the real prevalent in South Africa during the 1950s and 1960s ignored or attempted to suppress. Indeed, it is these "owners" - to borrow a term Hope uses (Wood, 1998:61) - that promulgate such versions of reality who would be particularly eager to condemn the fantastic as escapist. 5

Hope, on the other hand, takes imagination seriously precisely because it is neither insubstantial nor unimportant. The fact that apartheid was based on a fantasy of innate racial superiority indicates how the imaginary can have colossal significance in the physical world. For Hope, one of the horrible ironies of Nationalist Party-dominated South Africa lay in the way it repressed and denigrated imagination, while imposing a version of reality in which a range of areas associated with the fantastical were interwoven with the pragmatic.

\section{Imaginative recreation}

Certainly, when we look more closely at Hope's fantastical recreations of the real, it becomes evident that they are more than equal to the situation with which they engage, extending beyond the reach and the comprehension of the power structures otherwise dominant.

The most recently quoted extract from Black Swan for instance, leads us towards vistas that $A$ Separate Development (1981) and Learning to Fly (1990) suggest, but are not intended to attain. As the above extract makes clear, Lucky does not see the limitations of his situation. Instead, he looks beyond them, and through his eccentric imaginative inventiveness, his environment becomes astounding and marvellous. In this way, he affirms all those aspects of experience that all the other members of his society lack access to, restricted as they are by the conservatism of their society, while the dreary, bleak nature of their township surroundings is expressive of the way their lives have been deliberately stripped of anything that

4 This quotation comes from an unedited version of an interview with Christopher Hope, included as an appendix to my Ph.D. thesis. An edited version of this interview was published by the English Academy Review in 1998.

$5 \quad$ Hope describes dominant discourses and ideologies as being normalised by "owners": those who have a secure place at the centre of their society (Wood, 1998:60). 
might brighten, augment or enhance them. Through his apparent evasion of reality, Lucky in fact opens it up to new dimensions. This, of course, is the essential point, for Hope is intent upon showing how imagination has the capacity to recreate the real in such a way that it overrides those definitions of the latter intended to enforce submission to established systems of control.

Certainly, as Black Swan progresses, it becomes increasingly clear that the real significance of Lucky's situation lies in its symbolic implications, rather than in the physical fate that befalls him. Hope makes the following comment:

[W] hat Lucky does is not so much as to escape. Escapism is an unreal thing, it's not that. What Lucky possesses is imagination and the form of imagination that he possesses is deeply subversive. It turns things on their heads. ... [E]ven at the end it seems to me that it's the power of Lucky's transforming imagination and his capacity for subversion, above all, that frees him. Not accepting what he's told, indeed hearing more or less what he's told and then remaking it, reworking it in his own fashion (Wood, 1998:61).

At this point, Hope himself qualifies the idea of escape, acknowledging its problems, although elsewhere he seems to embrace it more uncritically. Here, he describes the type of liberation he believes that imaginative flights can lead into: an expanded, enhanced perception of the real and the freedom to interrogate and recreate the conventionalised dictates that can constrain the individual members of a society.

More than anything else, it is forms of mental control - William Blake's "mind-forg'd manacles" (1977:14-31) - that Hope objects to, and which he seeks to undermine. In Discipline and Punish, Foucault shows how, from the early nineteenth century onwards, there was an increasing shift towards non-corporal forms of control and chastisement, focusing on the soul, rather than the body. In a society like South Africa's during apartheid, which sought as much to subjugate the human spirit as the body, it is entirely appropriate that Hope, who engages with this society at the level of fiction, presents his characters attaining freedom in an imaginative sense, rather than a physical one.

\section{Conclusion}

In closing, then, we can conclude that while the transformation of his protagonists' physical circumstances may not be possible within the 
world of Hope's texts, transformation can take place in terms of the way in which we come to perceive certain established aspects of that world. We have one well-known precedent for this in the fantastical, metaphorical description of Coketown in Charles Dickens's Hard Times. Martha C. Nussbaum (1995:43) puts it well:

Even while it depicts the monotony and soul-crushing dreariness of the Coketown factory, it triumphs over it in language, comparing the coils of steam to serpents, the moving machine parts to 'melancholy-mad elephants' ... . The novel cannot describe its opposition without doing battle with it, approaching it through Fancy and playfully surmounting it.

Likewise, in Hope's fiction, a torture device in $A$ Separate Development becomes a "souped-up mincer" and in "Learning to Fly" we are offered the siren-like spectacle of a black man soaring through the sky, which lures that bastion of apartheid-style brutality, Du Preez, to his doom.

Over and above such examples, however, one of the clearest instances of this fanciful overcoming of reality occurs in a story that is filled with apparent defeat and humiliation, "Ndbele's People". A black priest, Ndbele, rejected by his white congregation, returns to his desolate, poverty-stricken homeland. Hope, in closing, emphasises what it is that Ndbele creates as an alternative to his congregation:

The dancing policemen were the first of a set of monumental figures which soon were to occupy every corner of the garden. ... Next came the Dying Priest Attended by a Child ... [l]t was with a terrible shock that Father O'Shea recognised that the features were modelled on his own. A moment's inspection showed him that the two dancing policemen had the faces of Stockenstrom and Sam Mervyn ...

[Ndbele's] last great work, a tableau of no less than sixteen figures, the Virgin attended by her Golfers, took him almost three months to build and showed the Virgin upon a rock, rather reminiscent of the Little Mermaid, receiving a deputation of golfers ... (Hope, 1990:75)

Ndebele's parishioners are incorporated into figures involving the banal, the religious, the sentimental. Various hallowed South African icons, such as sport and the police, are also included. Faced with misunderstanding and abuse from the white community within which he is placed, Ndbele seeks to remodel it, literally. In the world of his art, conflict, division and contradiction are overridden and resolved 
into a fanciful, ironic, heterogeneous whole. A similar type of transformation takes place when Ndbele and his "people" find an eventual place of refuge on the rugby field in the grounds of the giant casino complex in Nbdele's homeland. The rugby field, a symbol of white South African establishment, and the casino (a central feature of the bantustan system) become, instead, parts of a space within which the fantastical and the mystical are allowed free sway. Control is thwarted, as Ndbele and his people come to represent the potential for the uncontrollable, even within a society as dictatorial as that of South Africa during apartheid.

It is in his capacity to suggest precisely this, particularly through his use of the fantastic, that the most significant feature of Hope's work lies. The types of freedoms suggested in Hope's earlier writing remain significant in post-1994 South African fiction. The political scenario may have changed, but a sense of constraint and confinement remains a key concern in contemporary South African novels in English. In Zakes Mda's The Colour of Redness (2000) and The Madonna of Excelsior (2002), for example, the protagonists are hampered by the weight of the past they carry into the present with them. This threatens to block their capacity for independent growth; while the political manoeuvring taking place around them and the tantalising promises of material gain that are dangled before them weave a web that could hold them fast. Similarly, the narrator in Michiel Heyns's latest novel is initially The Reluctant Passenger (2003) - helpless and passive, carried along by the force of history and the manipulations of the wealthy and powerful. But, while both Heyns and Mda reveal possibilities for subverting or breaking free of the various forms of disempowerment and control depicted in their novels, other writers emphasise a sense of restriction and entrapment. For instance, the central protagonists of A.P. Brink's Rights of Desire (2000) and J.M. Coetzee's Disgrace (1999) move in a world in which resigned acceptance of the severe limitations that beset them seems the most viable response. Moreover, the sense of tedium that Hope so deplored still features in various writers' depictions of contemporary life in this country. For example, The Reluctant Passenger, set just after the 1994 elections, and Ivan Vladislavic's novels and short stories repeatedly draw attention to the blandness and monotony of middle-class South African existence. In turning back to Hope's earlier work, then, we encounter possibilities that contemporary South African writers, still searching for new imaginative registers, ten years after the demise of apartheid, might continue to find relevant. 
It is all too easy to view Hope's fiction as memorable primarily for its darkly satirical vision, yet the most remarkable quality of his writing lies not so much in this aspect as in the way in which, in creating a South Africa that is "the capital of walls", he presents us with instances in which those walls are surmounted and what lies beyond them is glimpsed.

\section{List of references}

BAKHTIN, M. 1981. The dialogic imagination. Austin: University of Texas Press. BAKHTIN, M. 1984. Rabelais and his world. Bloomington: Indiana University Press.

BOEHMER, E. 1998. Endings and new beginning: South African fiction in transition. (In Attridge, D. \& Jolly, R., eds. Writing South Africa: literature, apartheid and democracy 1970-1995. Cambridge: Cambridge University Press. p. 43-56.)

BRINK, A.P. 2000. The rights of desire. London: Secker \& Warburg.

COETZEE, J.M. 1992. Doubling the point: essays and interviews. Cambridge: Harvard University Press.

COETZEE, J.M. 1999. Disgrace. London: Vintage.

DELIUS, A. 1982. Brothers in Bedlam. Times Literary Supplement: 4, Nov. 5.

FOUCAULT, M. 1977. Discipline and punish: the birth of the prison. Harmondsworth: Penguin.

GORDIMER, N. 1973. The novel and the nation in South Africa. (In Killam, G.D., ed. African writers on African writing. London: Heinemann. p. 33-52.)

GREEN, M. 1997. Novel histories: past, present and future in South African fiction. Johannesburg: Witwatersrand University Press.

HEYNS, M. 2003. The reluctant passenger. Cape Town: Oxford University Press.

HOLQUIST, M. 1981. Introduction. (In Bakhtin, M. Rabelais and his world. Bloomington: Indiana University Press. p. xiii-xxiii.)

HOPE, C. 1981. A separate development. London: Granada.

HOPE, C. 1984a. Kruger's alp. London: Abacus.

HOPE, C. 1984b. A view from the hills. (In Daymond, M.J., Jacobs, J.U. \& Lenta, M., eds. Momentum: on recent South African writing. Pietermaritzburg: University of Natal Press. p. 284-286.)

HOPE, C. 1985. The political novelist in South Africa. English in Africa, 12(1):41-46.

HOPE, C. 1987. Black swan. London: Hutchinson.

HOPE, C. 1988. White boy running. London: Secker \& Warburg.

HOPE, C. 1990. Learning to fly. London: Minerva.

HOPE, C. 1996. A South African abroad. Leadership, 5(2):110-112.

HOPE, C. 1997. Me, the moon and Elvis Presley. London: Macmillan.

JOFFE, P. 1989. An interview with Christopher Hope. English in Africa, 16(2):91-105.

MDA, Z. 2000. The heart of redness. New York: Picador.

MDA, Z. 2002. The madonna of Excelsior. Cape Town: Oxford University Press.

NUSSBAUM, M.C. 1995. Poetic justice: the literary imagination and public life. Boston: Beacon.

NYATSUMBA, K. 1992. Writing prose during transition. Staffrider, 10(42):91-95. 
SCHOONAKKER, B. 1999. Winning writer provokes British press to bash SA. Sunday Times: 33, Nov. 7.

WOOD, F. 1998. An interview with Christopher Hope. English Academy Review, 15:59-66.

WOOD, F. 2001. Fantasy and politics in South African literature: a comparative study of the use of the fantastic in selected works of Christopher Hope, Ivan Vladislavic and André Brink. Cape Town: University of Cape Town. (Doctoral thesis.)

\section{Key concepts:}

apartheid and South African literature

Hope, Christopher

satirical perceptions of Hope's work

the carnivalesque - means to create an alternative reality

the fantastic - as means to present another reality

\section{Kernbegrippe:}

apartheid en die Suid-Afrikaanse letterkunde

fantasie - middel om 'n ander werklikheid daar te stel

Hope, Christopher

karnavaleske - middel om 'n ander weergawe van die werklikheid te skep

satiririese persepsie van Christopher Hope se werk 